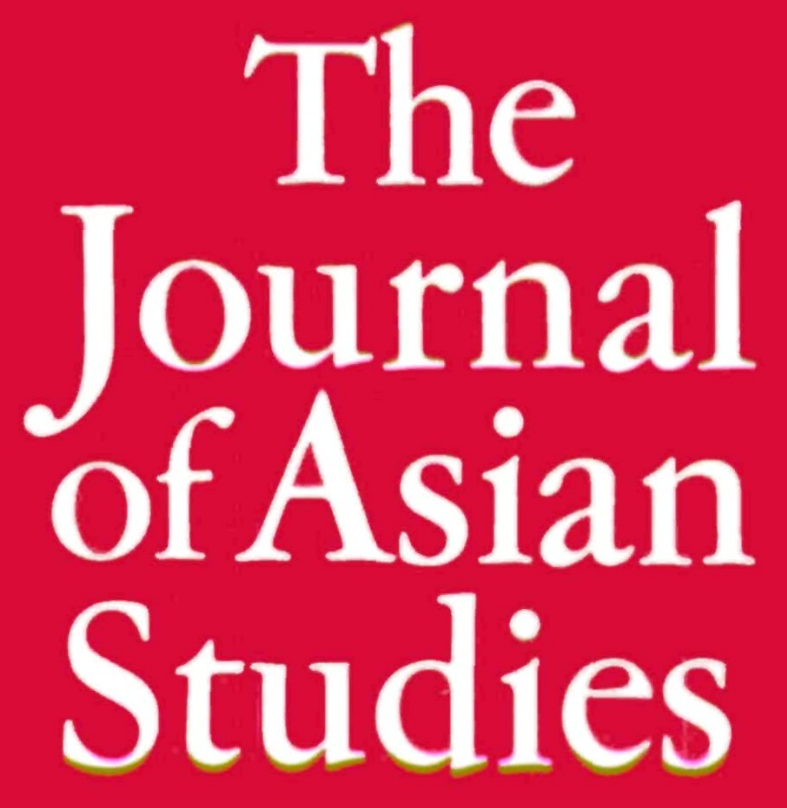

VOLUME 53

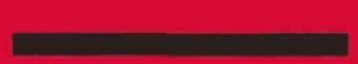

NUMBER 2

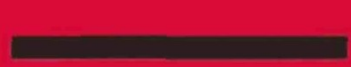

MAY 1994

PUBLISHED BY

THE ASSOCIATION

FOR ASIAN STUDIES, INC. 


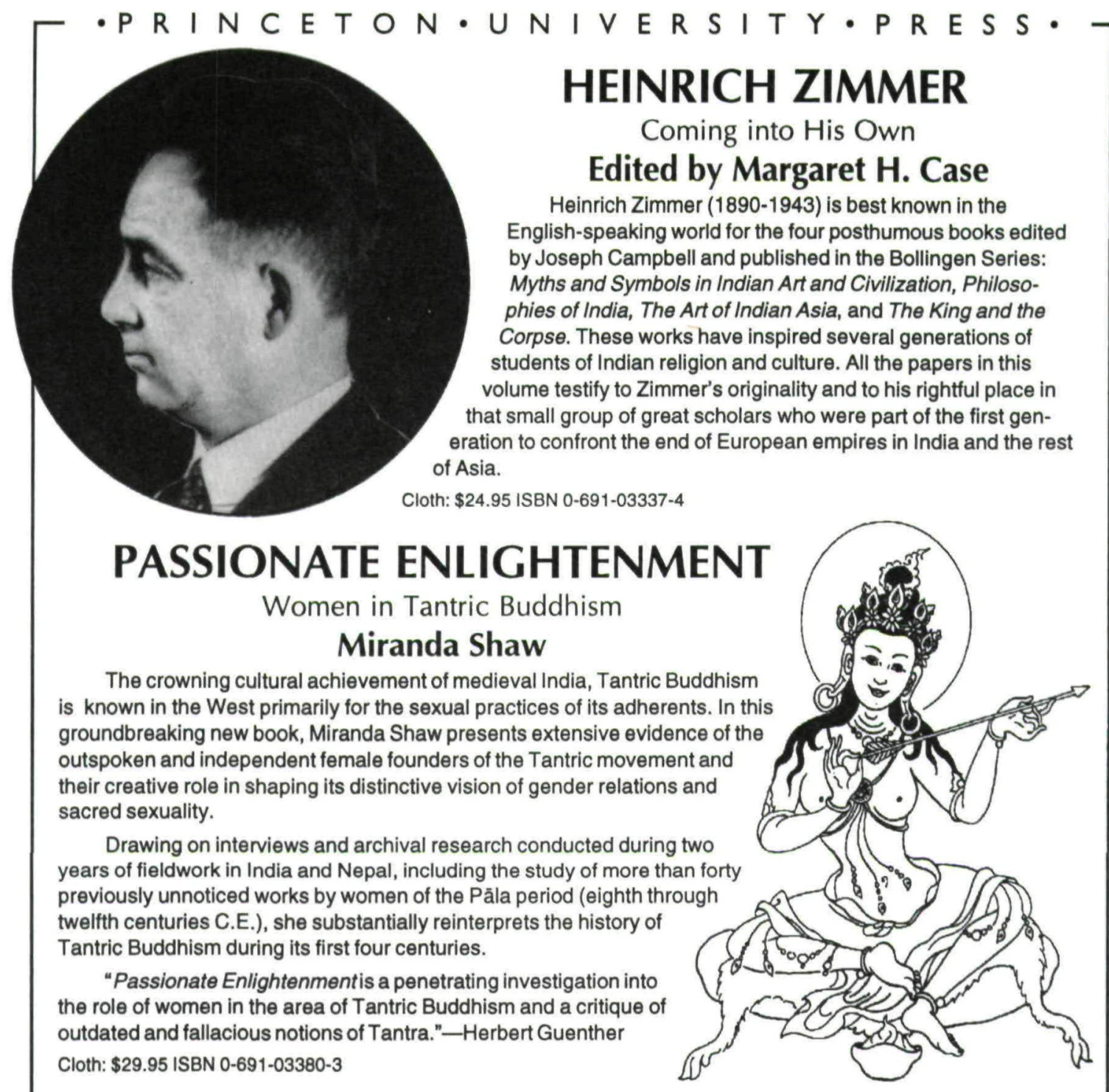

\title{
THE RĀMĀYANA OF VĀLMĪKI
}

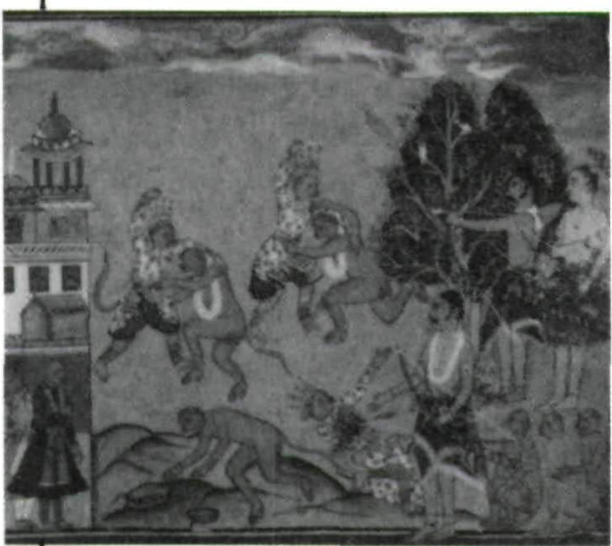

\author{
An Epic of Ancient India \\ Volume IV: Kișkindhākāṇḍa
}
Introduced, translated, and annotated by Rosalind Lefeber

This is the fourth volume of the translation of the critical edition of The Vãlmīki Rảmanyaṇa, India's most beloved and influential epic tale. This version differs significantly from the vulgate on which virtually all previous translations are based. It is accompanied by a scholarly introduction and extensive notes on the original Sanskrit text derived from a wide reading of traditional and modern texts, including several untranslated early Sanskrit commentaries.

Cloth: \$65.00 ISBN 0-691-06661-2 Due August 1994

\section{PRINCETON UNIVERSITY PRESS}




\title{
The \\ Journal \\ of Asian \\ Studies
}

Volume 53 - Number 2 - May 1994

\section{CONTENTS}

\author{
In This Issue 343
}

Articles

Rethinking Modernization and Modernity in Japanese History: A Focus on State-Society Relations

Tragedy and Salvation in the Floating World: Chikamatsu's Double Suicide Drama as Millenarian Discourse

Traditional Chinese Fiction-The State of the Field

A Uyghur Muslim in Qianlong's Court: The Meanings of the Fragrant Concubine

JAMES A. MILLWARD

The Soviet Union's Secret Diplomacy Concerning the Chinese Eastern Railway, 1924-1925

BRUCE ELLEMAN

The Interpretation of Thunder

CHARLES E. HAMMOND

\section{Book Reviews}

\section{Asia General}

BEFU (ed.), Cultural Nationalism in East Asia: Representation and Identity

CHOWDHUR Y and ISLAm, The Newly Industrialising Economies of East Asia

CONWAY and BOURQUE (eds.), The Politics of Women's Education:

Perspectives from Asia, Africa and Latin America

Dissanayake (ed.), Melodrama and Asian Cinema

LEASK, British Romantic Writers and the East:

Anxieties of Empire

LeE, New East Asian Economic Development: Interacting Capitalism and Socialism 
RidDell (ed.), To See the Dawn: Baku, 1920-First Congress of the Peoples of the East

SiMONIA, Syntbesis of Traditional and Modern in the Evolution of Third World Societies

SMART, Buddhism and Christianity: Rivals and Allies

W aldron (ed.), How the Peace Was Lost: The 1935 Memorandum "Developments Affecting American Policy in the Far East"

WARReN, $A b K u$ and Karayuki-san: Prostitution in Singapore, $1870-1940$

Young (ed.), The Rising Tide of Cultural Pluralism: The Nation-State at Bay

China and Inner Asia

BACHMAN, Bureaucracy, Economy, and Leadership in China: The Institutional Origins of the Great Leap Forward

Bergholz, The Partition of the Steppe: The Struggle of the Russians, Manchus, and the Zunghar Mongols for Empire in Central Asia, $1619-1758$

BYRD, The Market Mechanism and Economic Reforms in China

EBREY, The Inner Quarters: Marriage and the Lives of Chinese Women in the Sung Period

Gill, Chinese Arms Transfers: Purpose, Patterns, and Prospects in the New World Order

Henriot; Castelino (trans.), Shanghai 1927-1937: Municipal Power, Locality and Modernization BYRNA GOODMAN

HUANG; DE BARY (trans. and ed.), Waiting for the Dawn: A Plan for the Prince: Huang Tsung-bsi's Ming-i tai-fang lu

PERRY, Shanghai on Strike: The Politics of Chinese Labor

Richter, Zweifei am Altertum: Gu Jiegang und die Diskussion über Chinas Alte Geschichte als Konsequenz der "Neuen Kulturbewegung" ca 1915-1923

[Doubts on antiquity: Gu Jiegang and the discussion on China's ancient history as consequence of the New Culture Movement, 1915-1923] QINGJIA EDWARD WANG

SELDEN, The Political Economy of Chinese Development CARL RISKIN

SHIRK, The Political Logic of Economic Reform in China

STross, Bulls in the China Shop and Other Sino-American Encounters 
TSAl, Hong Kong in Chinese History, Community and Social Unrest in the British Colony, 1842-1913

Unger (ed.), Using the Past to Serve the Present: Historiography and Politics in Contemporary China

UNSCHULD (trans.), Forgotten Traditions of Ancient Chinese Medicine: A Chinese View from the Eighteenth Century [The I-hsüeh Yüan Liu Lun]

HSIUNG PING-CHEN

VAN DE VEN, From Friend to Comrade: The Founding of the Chinese Communist Party, 1920-1927

MARILYN A. LEVINE

YANG; NYLAN (trans.), The Canon of Supreme Mystery

SARAH A. QUEEN

Yu, To Save China, To Save Ourselves: The Chinese Hand Laundry Alliance of New York

Japan

BROWER (trans.), Conversations with Shötetsu

THOMAS H. ROHLICH

DAvis, Japanese Religion and Society: Paradigms of Structure and Cbange

DOWER, Japan in War and Peace: Selected Essays

WAYNE C. MCWILLIAMS

GERLACH, Alliance Capitalism: The Social Organization of Japanese Business

BRUCER. DALGAARD

GORDON (ed.), Postwar Japan as History

MICHAEL A. BARNHART

Hatamiya, Righting a Wrong: Japanese Americans and the Passage of the Civil Liberties Act of 1988 DONALD TERUO HATA, JR.

Hirata, The Poetry and Poetics of Nishiwaki Junzaburō: Modernism in Translation

Kubozono, The Organization of Japanese Prosody

MARY E. BECKMAN

MARSHALL, Academic Freedom and the Japanese Imperial University, $1868-1939$ YOSHIKUNI IGARASHI

MEECH; with HıROSHI and KÖHLER, Rain and Snow: The Umbrella in Japanese Art

LAURA S. KAUFMAN

Mullins, Susumu, and SW ANSON (eds.), Religion and Society in Modern Japan: Selected Readings

NAGATA, Legacy of Injustice: Exploring the Cross-Generational Impact of the Japanese American Internment

JUDY TACHIBANA

Nagatomo, Attunement through the Body

TAITETSU UNNO

PINGUET, Voluntary Death in Japan

EIJI SEKINE

RAMSEyer and Rosenbluth, Japan's Political Marketplace

BAI GAO

SAKAIYA; FIELDS and MARSH (trans.), The Knowledge-Value Revolution, or, A History of the Future 
SHIMAZAKI (trans.), Warrior Gbost Plays from the Japanese Nob Theatre

TERANISHI and KOSAI (eds.), The Japanese Experience

Korea

Ch'Ae; Chun (trans.), Peace Under Heaven:

A Modern Korean Novel

Cotton (ed.), Korea under Rob Tae-woo: Democratization, Northern Policy and Inter-Korean Relations JOHN KIE-CHIANG OH

Mosher (ed.), Korea in the 1990s: Prospects for Unification

PIHL and FuLTON (eds.), Land of Exile: Contemporary Korean Fiction

South Asia

BROWER, Sherpa of Khumbu: People, Livestock, and Landscape

Burki and Baxter; with LA POrTe and AzFar, Pakistan Under the Military: Eleven Years of Zia ul-Haq

Chatterji, Trade, Tariffs and Empire: Lancashire and British Policy in India, 1919-1939

Desai and Mason (eds.), Gods, Guardians, and Lovers: Temple Sculptures from North India, A.D. 700-1200 GERI H. MALANDRA

Doniger (ed.), Purāna Perennis: Reciprocity and Transformation in Hindu and Jaina Texts

HAWLEY and MANN (eds.), Studying the Sikbs: Issues for North America

INGRAM, Britain's Persian Connection 1798-1828: Prelude to the Great Game in Asia EDWARD B. JONES

KATZ (ed.), The Traditional Indian Theory and Practice of Music and Dance

Kamath, The Political Economy of Suppressed Markets: Controls, Rent Seeking and Interest-Group Bebaviour in the Indian Sugar and Cement Industries

KothARI, New Fiscal and Economic Strategies for Growth in Developing Countries

LORENZEN, Kabir Legends and Ananta-Das's Kabir Parachai

MALIK (ed.), Dilemmas of National Security and Cooperation in India and Pakistan

MCLEOD, The Sikbs: History, Religion, and Society VERNE A. DUSENBERY 
Müller, Das Brabmanische Totenritual Nach der Antyestipaddhati des Nārāyanabbat!̣a

NAYAR, India's Mixed Economy: The Role of Ideology and Interest in Its Development

Nayar, The Political Economy of India's Public Sector: Policy and Performance

Noman, Pakistan: Political and Economic History Since 1947

Prakash (ed.), The World of the Rural Labourer in Colonial India

R AY (ed.), Entrepreneurship and Industry in India, 1800-1947

RIZvI, Pakistan and Geostrategic Environment: A Study in Foreign Policy

ROBERTS (trans.), The Seasons: Kälidäsa's

RUSSELL, The Pursuit of Urdu Literature: A Select History

Sawai; Oberhammer (ed.), The Faith of Ascetics and Lay Smärtas: A Study of the Sankaran Tradition of Sringeri

SEN, Colonies and the Empire: India, $1890-1914$

SRINIVAS, On Living in a Revolution and Other Essays

UNGEMACH, Samkara-Mandära-Saurabba: Eine Legende Über das Leben des Philosophen Samkara

\section{Southeast Asia}

\section{APINAN, Modern Art in Thailand: Nineteenth} and Twentieth Centuries

BAKKER, The Struggle of the Hindu Balinese Intellectuals: Developments in Modern Hindu Thinking in Independent Indonesia

BOYCE, The Philippines: The Political Economy of Growth and Impoverishment in the Marcos Era

Cushman, Fields from the Sea: Chinese Junk Trade with Siam during the Late Eighteenth and Early Nineteenth Centuries CARL A. TROCKI

Dirkse, Husken, and Rutten (eds.), Development and Social Welfare: Indonesia's Experiences Under the New Order 
Drooglever and Schouten (eds.), Officiële Bescheiden Betreffende de Nederlands-Indonesische Betrekkingen

$1945-1950$

GAfFAR, Javanese Voters: A Case Study of Election Under a Hegemonic Party System

GEAR, Earth to Heaven: The Royal Animal-shaped Weights of the Burmese Empires

Goodman (ed.), Japanese Cultural Policies in Southeast Asia during World War II

HeAD and GRinter (eds.), Looking Back on the Vietnam War: A 1990s Perspective on the Decisions, Combat, and Legacies

HIRSCH (ed.), The Village in Perspective: Community and Locality in Rural Thailand

HoOker (ed.), Culture and Society in New Order Indonesia

KARL G. HEIDER

KAHN, Constituting the Minangkabau: Peasants, Culture and Modernity in Colonial Indonesia

KLOKKE, Tantri Reliefs on Ancient Javanese Candi

LARKIN, Sugar and the Origins of Modern Philippine Society

MACINTYRE and JAYASURIYA (eds.), The Dynamics of Economic Policy Reform in South-east Asia and the South-west Pacific

Miettinen, Classical Dance and Theatre in South-East Asia

R. ANDERSON SUTTON

PertierRA (ed.), Remittances and Returnees: The Cultural Economy of Migration in llocos

ANITA BELTRAN CHEN

PHILliPS, The Integrative Art of Modern Thailand

ASTRI WRIGHT

PORTER, Vietnam: The Politics of Bureaucratic Socialism

DAVID HUNT

QuinN, The Novel in Javanese: Aspects of Its Social and Literary Character

REYNOLDS (ed.), National Identity and Its Defenders: Thailand, 1939-1989

SOPON, Bangkok Slums: Review and Recommendations

TAn Soo Beng, Bangsawan: A Social and Stylistic History of Popular Malay Opera

Sutton, Variation in Central Javanese Gamelan Music: Dynamics of a Steady State

TARLING (ed.), The Cambridge History of Southeast Asia Volume I: 
TARLING (ed.), The Cambridge History of Southeast Asia Volume II: The Nineteenth and Twentieth Centuries

TAYLOR, Forest Monks and the Nation State: An Antbropological and Historical Study in Northeastern Thailand RUTH-INGE HEINZE

TAYLOR and ARAgON, Beyond the Java Sea: Art of Indonesia's Outer Islands

VON DER MEHDEN, Two Worlds of Islam: Interaction between Southeast Asia and the Middle East WILLIAM R. ROFF

Welaratna, Beyond the Killing Fields: Voices of Nine Cambodian Survivors in America

Film and Video Reviews

Bates (prod. and dir.), Turnim Hed: Courtship and Music in Papua New Guinea LORRAINE V. ARAGON

VIDEOCHAMP (prod.), The Tale of Genji

KAREN L. BROCK 668

Other Books Received 670

\section{Obituary}

PETER ANANDA (1926-1993)

A. KOHAR RONY

Communication to the Editor 676 


\title{
The Journal of Asian Studies
}

\author{
University of Wisconsin-Milwaukee, Milwaukee, Wisconsin 53201
}

Editorial Board. Editor: David D. BuCK, University of Wisconsin-Milwaukee. Assistant Editors: China, JEFFrey C. KinkLEY, St. Jobn's University; Japan, JAMES BARTHOlOMEw, Obio State University; Korea, JaHyun KIM HABOush, University of Illinois; Sourh Asia, ANAND Yang, University of Utab; Southeast Asia, SUSAN D. Russell, Northern Illinois University. Book Review Editors: China and Inner Asia, Charles W. HAYFORD, Nortbwestern University; Japan, Patricia Wetzel, Portland State University; Korea, Young Whan KiHL, Iowa State University; South Asia, SANDRIA FreITAG, University of California, Berkeley; Sourheast Asia, CraIG LOCKARD, University of Wisconsin-Green Bay.

Editorial Staff. Manuscript Editor: Gladys BovéE. Editorial Assistants: Charles S. YOUNG and CYNTHIA A. BIEDRZYCKI, University of Wisconsin-Milwaukee.

Sponsoring Institutions. University of Michigan, University of Wisconsin-Milwaukee.

The Journal of Asian Studies (ISSN 0021-9118), founded in 1941 and known until September 1956 as the Far Eastern Quarterly, is published by the Association for Asian Studies (formerly The Far Eastern Association) in February, May, August, and November. The annual institutional subscription rate for the Journal (including the Bibliography of Asian Studies and the Doctoral Dissertations on Asia) is \$95, postage included. Regular members of the Association for Asian Studies receive the Journal as part of their annual membership. Single issues of the Journal and Bibliography published after February 1974 are available through the Secretariat of the Association. Issues published prior to 1958 may be purchased from A.M.S. Reprints, 56 East 13th Street, New York, NY 10003 .

\section{GUIDELINES FOR SUBMISSION OF MANUSCRIPTS}

Completed manuscripts, inquiries about material for possible publication, and correspondence to the editor should be sent to the Joumal's editorial offices:

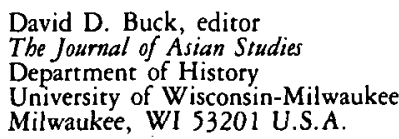

Phone: 414-229-396

Fax: 414-229-6827

E-mail: davebuck@csd4.csd.uwm.edu

Article manuscripts, including notes, should not exceed 40 pages in length. Please submit four copies. All submitted work should be double-spaced, including extracts, notes, and references. Consult recent issues of the Journal as a guide to format. Footnotes should be as few as possible, and typed double-spaced at the end of the text. Documentation should follow the style recommended in sections 16.3 through 16.28 of the Chicago Manual of Style, 14th ed. (Chicago: University of Chicago Press, 1993), pp. 641-51. Authors are encouraged to submit tables, figures, maps, photographs, and orher illustrations along with their manuscripts; please consult the editor for specifications. Additional guidelines on manuscript preparation will be sent upon request.

All manuscripts submitted to the JAS are expected not to have been published elsewhere and not be under review for possible publication elsewhere. Unsolicited book reviews are not accepted.

Books for review and correspondence concerning reviews should be sent to the appropriate book review editor:

Asia General: David D. Buck (address above)

China and Inner Asia: Charles W. Hayford, Department of History, Northwestern University, Evanston, IL 60208

Japan: Patricia Wetzel, Department of Foreign Languages, Portland State University, Portland, OR 97207

Korea: Young Whan Kihl, Department of Political Science, Iowa State University, Ames, IA 50011

South Asia: Sandria Freitag, 501 Rhode Island, San Francisco, CA 94107

Southeast Asia: Craig Lockard, Social Change and Development, University of Wisconsin-Green Bay, Green Bay, WI 54302

Articles in The Jourmal of Asian Studies represent neither the views of the Association for Asian Studies nor those of the JAS editors. The editor is responsible for the final selection of the content of the Joumal and reserves the right to reject any material deemed inappropriate for publication. Responsibility for opinions expressed and for the accuracy of facts published in articles and reviews rests solely with the individual authors.

Requests for permission to reprint and all correspondence regarding membership, subscriptions, advertising, or business should be addressed to the Association for Asian Studies, 1 Lane Hall, University of Michigan, Ann Arbor, MI 48109. The Jourmal is indexed in the Social Sciences \& Humanities Index and Book Review Index and abstracted in Historical Abstracts and America: History and Life. It is also available on film through University Microfilms, Ann Arbor, MI 48109.

Second class postage paid at Ann Arbor, Michigan, and at additional second class entry. POSTMASTER: Send address changes to The Association for Asian Studies, I Lane Hall, University of Michigan, Ann Arbor, MI 48109. 